\title{
Studies on the perennial pea Vavilovia formosa (Fabaceae) of mountain Aknasar population (Gegham Highland) and under ex situ conditions in the Botanical Gardens of Armenia
}

\author{
Janna Akopian · Anahit Ghukasyan · Zhanna Hovakimyan · \\ Lora Martirosyan · Gevorg Zaroyan
}

Institute of Botany after A. L. Takhtajyan of NAS RA, Yerevan, Republic of Armenia

\begin{abstract}
Summary: Wild perennial pea Vavilovia formosa is a relic and an endangered species of the upper alpine flora of Armenia, specialized to scree habitats. The populations of $V$. formosa in Armenia, as well as in other sites of the world, are in danger of extinction and need both in situ and ex situ complementary investigation and conservation. Present article contains information on $V$. formosa Aknasar mountain population studies. Data on natural conditions, flora composition, ecological and coenotic characteristic of the habitat and bio-ecological features of $V$. formosa are given. The present state of Vavilovia population of mountain Aknasar is satisfactory. The activation of seed reproduction along with vegetative propagation is observed. One of the natural threats leading to the change and reduction of Vavilovia population was estimated to be the overgrowing of mobile scree habitats with turf-forming grasses, which creates conditions for the mountain-meadow vegetation development. $V$. formosa ex situ conservation strategy is one of the possible ways of its adaptive capacity estimation to environment changes as well as for its saving and using in basic and applied researches. An introductory experiment on the cultivation of Vavilovia in the Yerevan and Sevan Botanical Gardens has started, and some data on bio-morphological and eco-physiological peculiarities under ex situ conditions were obtained.
\end{abstract}

Key words: Aknasar mountain, Armenia, bio-ecological studies, ex situ cultivation, Vavilovia formosa

\section{Introduction}

Wild perennial pea Vavilovia formosa (Steven) Fed. (Fabaceae) is a relic and an endangered species of the alpine flora of Armenia, highly specialized to small areas of moving detritus and scree. Vavilovia Fed. (Fedorov,

Corresponding author:

akopian_janna@inbox.ru

Acknowledgement:

This work was made possible by a research grant from the Armenian National Science and Education Fund based in New York, USA (ANSEF Grant Plant4819) for which we would like express our gratitude. We are gratitude to the Director of the Center for Ecological-Noosphere Studies of NAS RA, Doctor of Geological-Mineralogical Sciences, A. K. Saghatelyan for the assistance rendered in the organization of testing of Aknasar mountain soil samples, to Dr. T. Alexanyan for consultations on Gegham highland climatic conditions ("The Armenian Tree Project" Charitable Foundation) and Dr. A. Gasparyan (WWFArmenia) for identification of lichens species of Mt. Aknasar.

Cite this article:

Akopian J., Ghukasyan A., Hovakimyan Z., Martirosyan L., Zarovan G. (2019). Studies on the perennial pea Vavilovia formosa (Fabaceae) of mountain Aknasar population (Gegham Highland) and under ex situ conditions in the Botanical Gardens of Armenia. Ratar. Povrt., 56 (1), 13-19.
1939) is a separate branch in the tribe Fabeae (Fabaceae). Its origin is associated with upper alpine, high mountain zones of Great and Lesser Caucasus, North and North-Western Iran, Northern Iraq, Anatolia, Syria and Lebanon.

In Armenia, Vavilovia occurs on Gegham highland, on the Zangezur mountain range and on Syunik highland. Gegham highland is a part of the volcanic zone of Armenia, it arose as a result of volcanic effusions of upper tertiary and quaternary time, and was partially altered by glacial and erosion processes (Aslanyan, 1958). Highland is dominated by about 30 large crater cones with maximum height $3598 \mathrm{~m}$ asl (Azhdahak peak). In some of the craters small lakes have been formed. The climate is temperate continental and in top areas - cold mountain. By the Yeratmber weather station database, the average annual temperature is $-2.5^{\circ} \mathrm{C}$ (from $-6.4^{\circ} \mathrm{C}$ to $+1.7^{\circ} \mathrm{C}$ ), precipitation $-871 \mathrm{~mm}$. Snow lasts about 218 days a year. Wind speed reaches $25-30 \mathrm{~m} / \mathrm{s}$. Slopes with moving detritus and screes of volcanic light porous slag are found on almost all the cones. As a result of the 
continuous process of weathering of rocks, a series of transitions from large rocks to fine sandy crushed stone are formed. Primary and secondary by the origin, as well as fixed and mobile screes of large-gravel, fine-grained and sand-like slag are observed on Gegham mountains (Kazaryan, 1939).

The populations of $V$. formosa in Armenia, as well as in other sites of the world, due to the narrow specificity of habitat requirements, are considered to be regressing (Tamanyan et al., 2010; Akopian et al., 2010; Mikic et al. 2013, 2014; Vishnyakova et al., 2016). Narrow ecological amplitude, isolation and fragmentation of Vavilovia populations are among expansion limiting factors, the main human-induced threat is grazing. Another possible threat to $V$. formosa is forecasted warming, conditioned by the influence of Global climate change, which can lead to redistribution of territories of different ecosystems. By the niche modelling results, $V$. formosa is expected to have further range reduction in various scenarios for climate change (Smýkal et al., 2017).

Taking into account such predictions, a better knowledge of the evolutionary potential of the rare species respond to environmental change is needed. Targeted bio-ecological studies to identify the adaptive potential of Vavilovia to forecast warming on the territory of Armenia has not been carried out yet. That is why a special monitoring for Vavilovia populations status estimation is demanded.

$V$. formosa ex situ conservation strategy is one of the possible ways of its adaptive capacity estimation to environment changes, as well as for its saving and using in basic and applied researches. The most important goal in Vavilovia ex situ cultivation is to grow the plants that are capable of developing reproductive organs and produce seeds. $V$. formosa has a high potential for breeding, due to its adaptive features: perennial life cycle, tolerance to frost, drought, pests and diseases. In case of $V$. formosa flowering in culture, interspecific and intergeneric hybridisation can to be done (Mikich et al., 2014). Nowadays, according to the definition of Botanic Gardens Conservation International (BGCI) in the International Agenda for Botanic Gardens in Conservation (IABGC), an important role of the rare and endangered plants ex situ conservation is given to botanical gardens.

This study was carried out with the aim of $V$. formosa bio-ecological peculiarities evaluation in natural habitats of Gegham mountains and under ex situ conditions in Botanical Gardens of Armenia.

\section{Materials and Methods}

Studies of Vavilovia were carried out in the upper alpine zone of Mt. Aknasar, in Yerevan and Sevan Botanical Gardens and in the Institute of Botany NAS RA. Field works were implemented during the expeditions to Kotayk and Gegharkunik districts of RA in June-October 2018. The following methods used in research: a unified system of environmental monitoring
(Hill et al., 2005); bio-ecological (Serebryakov, 1962); phaenological (Beydeman, 1974); ex situ cultivation of wild plants (Akhverdov, Mirzoeva, 1949); water regime, transpiration, chlorophyll and photosynthesis intensity determination (Osipova, 1947; Practicum on plant physiology, 1990; Mezhunts, Navasardyan, 2010), measurements were taken from $11 \mathrm{am}$ to $1 \mathrm{pm}$, the determined results were subjected to statistical processing. Site monitoring involves: visual observation of population and individual plant species, photographic records, preparing permanent squares (quadrats) $1 \times 1$ meter for field records, measuring of site factors (using GPS device, $\mathrm{pH}$ and Moisture Meter, Thermometer with Hydrometer TA-138). Analysis of soil samples was done in the Center for Ecological-Noosphere Studies of the NAS RA.

\section{Results and Discussion}

The Gegham highland population of Vavilovia is the largest one in Armenia. During the field investigations of past years from 1929 to recent time Vavilovia was recorded on south-eastern and southwestern mobile scree slopes of mountains Aknasar (3258 m), Vishapasar (3157 m), Spitakasar (3555 m), Sevkatar (Sevsar) (3225 m), and in large numbers - in the neighborhood of lake Aknalich $(3032 \mathrm{~m})$ and on volcanic cones surrounding the lake (Kazaryan, 1939; Fjodorov, 1939; Makasheva et al., 1973; Baloyan, 2004; Akopian et al., 2010, 2018; data of ERE and EREU Herbarium materials).

With the aim of bio-ecological studies and botanical inventory of Vavilovia population, scientific expeditions to mountain Aknasar were realized on July 11 and on September 13, 2018. Population is located on southeastern moving scree slope of mountain Aknasar, it has an area of 0.12 ha at an altitude of $3135-3150 \mathrm{~m}$ asl. The slope is sunlit and sun-warmed, covered by a layer (up to $4-6 \mathrm{~cm}$ ) of red and grey volcanic fine-grained slag of $0.5 \mathrm{~cm}$ to $2-3 \mathrm{~cm}$ in size and by larger tuff stones of up to $20-30 \mathrm{~cm}$. The base of the slope is large rocky. The water that is formed during the melting of the snow from the top of mountain is absorbed by the slag under which the aquifer layer is formed. The habitat is characterized by precipitation during the spring and autumn-winter months, strong heating of the soil in the summer dry period, and winds that dry up the surface layer of slag and the adjacent layer of soil. These conditions lead to the xerophytization of the plants growing here. The following parameters were obtained for climatic and soil conditions of Aknasar: daytime air temperature is $26.5^{\circ} \mathrm{C}$, the air temperature in the sun is $32.1^{\circ} \mathrm{C}$, and relative air humidity is $37 \%-40 \%$. The results of soil chemical and mechanical analysis are represented in Table 1 . Sandy loam soil moisture under the gravel on the depth about $40-50 \mathrm{~cm}$ content is 1 $1.2 \%$. The high percentage of sand $(72.2 \%)$ in the soil promotes water infiltration to deeper layers, which creates dryness both on the scree slag and under it. 


\begin{tabular}{lll} 
Table 1. Soil chemical & & Determined \\
and mechanical & indicators & Outcomes, \% \\
\cline { 2 - 3 } composition of & $\mathrm{K}$ & 0.00085 \\
Vavilovia formosa habitat & $\mathrm{K} 2 \mathrm{O}$ & 0.00102 \\
on Mt. Aknasar & $\mathrm{Na}$ & 0.00075 \\
& $\mathrm{Cu}$ & $2.66 \cdot 10^{-5}$ \\
& $\mathrm{~Pb}$ & $3.2 \cdot 10^{-4}$ \\
& $\mathrm{P}_{2} \mathrm{O}_{5}$ & 0.95 \\
$\mathrm{SO}_{4}$ & 0.0082 \\
& $\mathrm{~N}$ total & 0.52 \\
& $\mathrm{Ca}$ & 0.008 \\
& $\mathrm{Mg}$ & 0.004 \\
& $\mathrm{Cl}$ & 0.0084 \\
& $\mathrm{HCO}-$ & 0.0183 \\
& $\mathrm{CaO}$ & 1.68 \\
& $\mathrm{Hummus}$ & 37.0 \\
& pH & 6.38 \\
& Soil type & Sandy loam \\
& Sand & 72.2 \\
& Clay & 5 \\
& Silt & 22.2 \\
\hline
\end{tabular}

Vegetation on scree habitat is low with surface coverage about $20-25 \%$. The density of Vavilovia population is from 40 to 150 plant samples per 1 sq. meter. Samples of Vavilovia represent $30-85 \%$ of the total number of plants per 1 sq. meter. Plants are represented by three life forms: annual, biennial and perennial herbs. The leading role in the vegetation cover of Aknasar slopes belongs to low-growing perennial herbs. The floristic composition of studied vegetation is represented by the following plant species, which were recorded in July-September aspects: Alliaceae - Allium schoenoprasum L.; Apiaceae Chamaesciadium acaule (M. Bieb.) Boiss.; Asteraceae Centaurea fischeri Willd., Cirsium rbizochephalum C. A. Mey., Doronicum oblongifolium DC., Leontodon bispidus L., Senecio vernalis subsp. sosnovskyi (Sof.) V.E.Avet., Tripleurospermum caucasicum (Willd.) Hayek; Brassicaceae - Sibbaldia procumbens L., Draba araratica Rupr., D. siliquosa M. Bieb., Erysimum gelidum Bunge, Coluteocarpus vesicaria (L.) Holmboe; Campanulaceae - Campanula glomerata L., C. saxifraga subsp. aucheri (A. DC.) Ogan., C. tridentata Schreb.; Caryophyllaceae - Arenaria dianthoides Sm.; Cerastium araraticum Rupr., C. szowitsii Boiss., Dianthus raddeanus Vierh., Minuartia oreina Schischk., Silene ruprechtii Schischk., S. saxatilis Sims; Fabaceae - Astragalus incertus Ledeb., Trifolium ambiguum M. Bieb., T. canescens Willd., T. trichocephalum M. Bieb.; Gentianaceae - Gentiana pontica Solt.; Lamiaceae Nepeta lamiifolia Benth., Thymus kotschyanus Boiss. \& Hohen., Ziziphora raddei Juz., Z. clinopodioides Lam.; Juncaceae - Luzula pseudosudetica V. I. Krecz.; Papaveraceae - Papaver fugax Poir., P. caucasicum M. Bieb.; Poaceae - Alopecurus tuscheticus Trautv., A. laguroides Balansa, A. textilis Boiss. subsp. textilis, Bromopsis variegata (M. Bieb.) Holub, Festuca woronowii Hack. subsp. cancasica (St.-Yves) E. B. Alexeev; Polygonaceae - Rumex acetosa L. subsp. acetosa;
Ranunculaceae - Ranunculus oreophilus M. Bieb.; Rosaceae - Alchemilla sericea Willd., A. grossheimii Juz., A. retinervis Buser; Rubiaceae - Asperula glomerata (M. Bieb.) Griseb., Galium sosnovskyi Manden.; Saxifragaceae - Saxifraga sibirica Pall. ex Ledeb.; Scrophulariaceae Pedicularis sibthorpii Boiss., Scrophularia olympica Boiss., Veronica orientalis Mill., and some others.

On many stones of mountain Aknasar, saxicolous lichens develop, which belong to the first settlers of stones, involved in the formation of scree. They give the stones a bright orange or grayish color. The following lichens species were discovered on Mt. Aknasar: Aspicilia desertorum (Kremp.) Mereschk., Candelariella vitellina (Ehrh.) Müll. Arg., Lecanora muralis (Schreb.) Rabenh., Rusavskia elegans (Link) S.Y. Kondr. \& Kärnefelt, Xanthoparmelia stenophylla (Ach.) Ahti \& D. Hawksw.

Scree plants specialization is aimed to fixing the underground organs in a moving substrate and to adapting the above-ground parts to the conditions of continuous slag coating. In Vavilovia this is achieved by the rapid formation of numerous thin, long, branched roots and above-ground sprouts, which, when filled with a substrate, continue to grow under its surface, take root and give a new leafy above-ground shoot. Roots and rooting above-ground shoots, spreading in all directions, consolidate scree and, thus, reach the state of their relative immobility.

Some fragments of the slope, free of vegetation, are firstly occupied by $V$. formosa, as well as by accompanying endemic species Gallium sosnovskyi described from Gegham highland (fig. 1). G. sosnovskyi is fine perennial herb, which also firmly fixes to the scree thanks to very dense and thin branching roots. Vavilovia plants are often found in small groups together with other species, such as Astragalus insertus, Campanula saxifraga subsp. aucheri, Cerastium araraticum, Thymus kotschyanus, Trifolium ambiguum, Tripleurospermum caucasicum. Intertwined by roots, these plants fix the scree in the place where they grow.

Mass flowering of Vavilovia was observed in early July (Fig. 1), on average ten days earlier than usual. Flowers fallen from night cold were not noted. During the autumn expedition in early September a large number of seedlings and juvenile Vavilovia plants were observed, which indicates the activation of seed reproduction along with vegetative propagation. The present state of Vavilovia population of mountain Aknasar can be estimated as satisfactory. No facts of grazing were noted on the altitude of investigated site.

Over the past decades, an increase in air temperature has been observed in Armenia (an average of $5.5^{\circ} \mathrm{C}$ ) (Melkonyan, Gevorgyan, 2017). With increasing altitude above sea level, a recession in the temperature increase is observed: temperature gradient up to $800 \mathrm{~m}$ asl is $1.7^{\circ} \mathrm{C}$, and at an altitude of $3000 \mathrm{~m}$ asl is $0.7^{\circ} \mathrm{C}$. Precipitation for 1935-2016 decreased in Armenia by 9\%. Above $2500 \mathrm{~m}$ asl there is a significant decrease in precipitation. As environmental niche modelling predicts, species may respond to temperature increase by moving to higher 
altitudes, which is hard for the high mountain $V$. formosa, as it already occurs at the elevations of $3000-3500 \mathrm{~m}$ in Armenia. The observations we carried out in natural habitats showed that the discussed scenario of Vavilovia range boundary rise is not feasible: this is prevented by the constant movement from above and the slag shedding from the top of the mountain. At the bottom the plant is limited by large stones, which cover a base of the slope. As a result, Vavilovia populations always occupy the middle part of the slope, which was also observed on the scree slopes near the Mt. Ukhtasar in Syunik district (Akopian et al., 2010). Being a highly specialized species, Vavilovia belongs to the biological group of high-altitude xerophytes (Akhverdov, Mirzoeva, 1964). In this regard, it can be assumed that the observed increase in temperature and a decrease in precipitation in the high-mountainous zone of Armenia cannot have appreciable threatening impact on Vavilovia vitality.

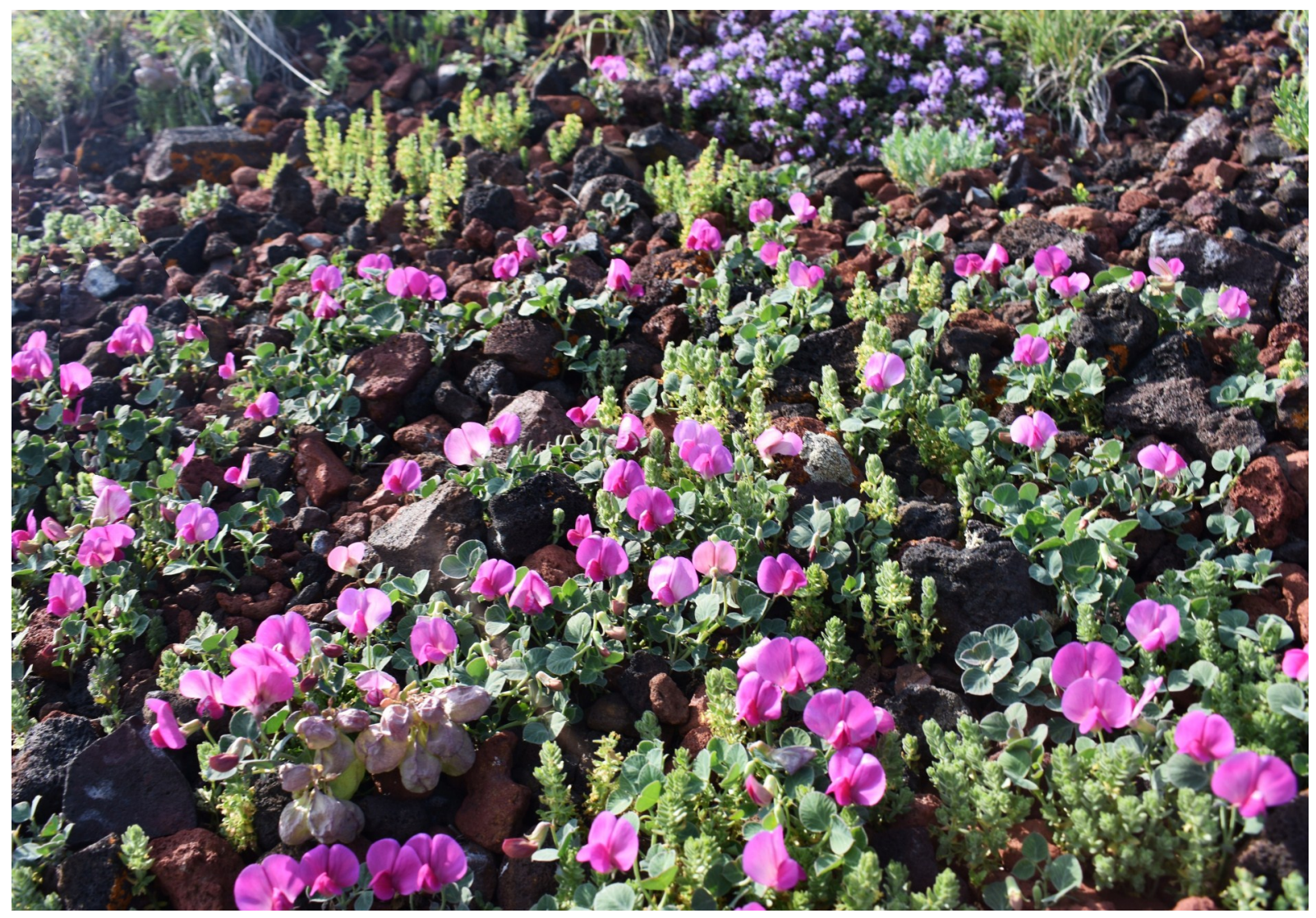

Figure 1. Fragment of V avilovia formosa Aknasar population, 11.07.2018, stage of the mass flowering

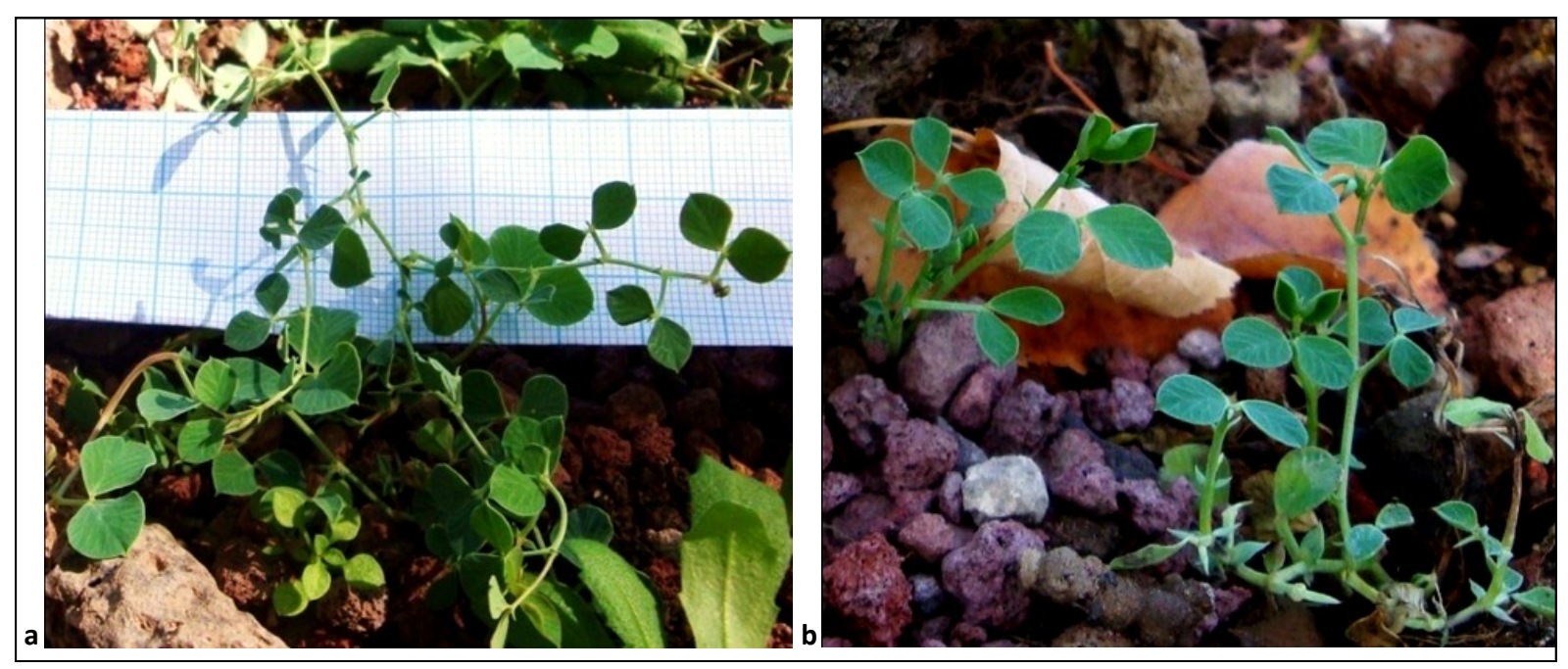

Figure 2. Vavilovia formosa growing at the "Flora and Vegetation of Armenia" Plot of the Yerevan Botanical Garden on September 25 (a) and on October 10, 2018 (b) 
The possible threat factor leading to the reduction of Vavilovia habitat can be the overgrowing of mobile scree with turf forming species of grasses Alopecurus tuscheticus, A. laguroides, A. textilis ssp. textilis, Bromopsis variegatus, Festuca woronowii ssp. caucasica, which creates conditions for the development of mountain-meadow vegetation. The overgrowing of Gegham ridge mobile screes was observed earlier by E. Kazaryan (1939) and it continues to the present. The expansion results of grass vegetation can be seen not far from Aknasar on the gentle slopes around Lake Aknalich (3090 masl). It led to vanishing of Vavilovia near Lake Aknalich, which occurs there in abundance in the first half of the past century. The grazing factor and using this area as pastures is a secondary negative factor accompanying the natural degradation of scree.

Attempts of $V$. formosa cultivation and ex situ conservation have been undertaken in Armenia from the 40 s to 80 s of the past centuryin the "Flora and vegetation of Armenia" Plot of the Yerevan Botanical Garden (Akhverdov, Mirzoeva, 1949, 1964). We have obtained some results of $V$. formosa ex situ cultivation in 2008-2010 (Akopian et al., 2010), and in laboratory conditions (Akopian et al., 2014).

Many years' experiences on the Armenian flora wild species cultivation by A. A. Akhverdov and N. V. Mirzoeva (1949, 1961, 1964) have revealed that alpine mesophyte species despite good care, grow not so well in the dry continental conditions of the Yerevan Botanical Garden. But in the same conditions, the upper alpine xerophytes, including Vavilovia, which in wild grow on well warmed lighted southern slopes, are more successfully cultivated. The southern position of mountain habitats and the sharply continental climate of the Yerevan Botanical Garden (severe winters and sharp fluctuations in day and night temperatures in summer) contribute to acclimatization of upper alpine xerophytes in the Garden.
In the frame of the present research $V$. formosa and some other alpine plant samples were transplanted (in July 12 and in September 14, 2018) from Mt. Aknasar in the Yerevan (stony semi-desert zone) and Sevan (high mountain steppe zone) Botanical Gardens. Climate condition average characteristics in JulySeptember in Mt. Aknasar and in Botanical Gardens are presented in Table 2.

Alpine hillocks were prepared in Botanical Gardens, using slag and earth from scree habitats, as well as tuff stones and mixture (with $\mathrm{pH}$ 6.8-7) of black soil, peat, red sand. Vavilovia samples were planted on the slopes of various exposures. Planting was carried out according to the method described in Akopian et al. (2010). After 7-12 days there were noticeable signs of rooting. Plant survival in the Sevan Botanical Garden was at first about 80-85\% and in the Yerevan Botanical Garden - about 60\%. Further, in the summer-autumn period, the growth and vegetative propagation of plants in the Yerevan Botanical Garden became more active, especially on the southeastern and south-western slopes of hillocks. The shoots reached 11-15 cm length with 14-17 leaves and 2-3 lateral branches with 5-6 leaves. The vegetation of the plants in Yerevan continued almost until the middle of November, they were green, new sprouts appeared permanently. The plants in the Sevan Botanical Garden developed more slowly, the shoots remained short, up to $5-8 \mathrm{~cm}$ in length, as in plants in natural places.

To identify the adaptive capacity of Vavilovia in nature and in the Yerevan Botanical Garden, measurements of such eco-physiological parameters as plastid pigments (chlorophyll, carotenoids), the intensity of photosynthesis, water regime (free and bound water, water deficiency) and transpiration, were made. The comparative study of some parameters in Vavilovia fresh leaves was carried out two months after transplantation from nature, when plants under ex situ conditions multiplied and the possibility of taking material appeared.

Table 2. Climate conditions in Mt. Aknasar, Yerevan and Sevan Botanical Gardens in July-September

\begin{tabular}{lccccc}
\hline Altitude (m) & $\begin{array}{c}\text { Air Temp } \\
\left({ }^{\circ} \mathrm{C}\right)\end{array}$ & $\begin{array}{c}\text { Relative air } \\
\text { humidity }(\%)\end{array}$ & $\begin{array}{c}\text { Soil moisture } \\
(\%)\end{array}$ & $\begin{array}{c}\text { Soil pH } \\
(\%)\end{array}$ & $\begin{array}{c}\text { Light } \\
(\text { Klux })\end{array}$ \\
\hline $\begin{array}{l}\text { In situ: Mt. Aknasar, 3135 -3150 m } \\
\begin{array}{l}\text { Ex situ: Sevan, 1950 m (under } \\
\text { partial shadow) }\end{array}\end{array}$ & 32 & 29 & 1.1 & $6.8-7$ & 40 \\
$\begin{array}{l}\text { Ex situ: Yerevan, } 1250 \mathrm{~m} \text { (under } \\
\text { partial shadow) }\end{array}$ & 20 & 56 & 8.5 & 6.9 & 33 \\
\hline
\end{tabular}

Table 3. The content of plastid pigments in Vavilovia formosa fresh leaves, depending on the height of growth in different climatic conditions, $\mathrm{mg} / 100 \mathrm{~g}$

\begin{tabular}{lccccc}
\hline Altitude (m) & Chl $a$ & Chl $b$ & Chl $a+b$ & Chl $a / b$ & Carotenoids \\
\hline $\begin{array}{l}\text { Mt. Aknasar 3150 m } \\
\begin{array}{l}\text { The Yerevan Botanical Garden 1250 } \\
\text { m }\end{array}\end{array}$ & 174 & 77 & 251,7 & 2,25 & 94 \\
\hline
\end{tabular}


Table 4. Intensity of water regime, photosynthesis and transpiration in fresh leaves of V avilovia formosa under in situ and ex situ conditions

\begin{tabular}{|c|c|c|c|c|c|c|c|}
\hline Altitude (m) & $\begin{array}{c}\text { Total water } \\
\% \text { wet } \\
\text { weight } \\
(\mathrm{M}, \mathrm{m})\end{array}$ & $\begin{array}{c}\text { Free } \\
\text { water } \% \\
\text { wet } \\
\text { weight } \\
(\mathrm{M}, \mathrm{m}) \\
\end{array}$ & $\begin{array}{c}\text { Bound } \\
\text { water } \% \\
\text { wet weight } \\
(\mathrm{M}, \mathrm{m})\end{array}$ & $\begin{array}{l}\text { Free/ } \\
\text { Bound }\end{array}$ & $\begin{array}{c}\text { Water } \\
\text { deficit } \% \\
\text { wet } \\
\text { weight } \\
(\mathrm{M}, \mathrm{m})\end{array}$ & $\begin{array}{l}\text { Transpiration } \\
\text { intensity } \\
\text { mg/g wet } \\
\text { weight, hr }\end{array}$ & $\begin{array}{l}\text { Photosynthesis } \\
\text { intensity } \\
\mathrm{mg} \mathrm{CO}_{2} / \mathrm{dm}^{2}-\mathrm{h}\end{array}$ \\
\hline $\begin{array}{l}\text { Mt. Aknasar } 3150 \\
\text { m 11.07.2018 } \\
\text { Mt. Aknasar } 3150\end{array}$ & 79 & 47.4 & 31.6 & 1.5 & 22.1 & 245.4 & 2.13 \\
\hline m 13.09.2018 & 81.7 & 56.1 & 25.6 & 2.2 & 23.3 & 363.6 & 2.8 \\
\hline $\begin{array}{l}\text { Yerevan } 1250 \mathrm{~m} \\
18.09 .2018\end{array}$ & 69.89 & 45.1 & 24.8 & 1.8 & 20.6 & 240.5 & 2.1 \\
\hline
\end{tabular}

The quantitative decrease in the chlorophyll content in Vavilovia leaves (Table 3) in mountains is explained by the biological feature considered as a plant response to highlight intensity, while more chlorophyll accumulates at a lower light intensity in the Botanical Garden. An increase in the content of carotenoids indicates their adaptive and protective effect for the photosynthetic apparatus in altered $e x$ situ growing conditions.

As a result of comparison of water regime indicators (Table 4), it was identified that in the arid conditions of the Yerevan Botanical Garden despite regular watering of the rocky hillocks and soil moisture of $7.5 \%$, the water deficit in Vavilovia was $20.6 \%$. It is not almost different from that of Aknasar (23.3\%), where soil moisture was $1.1 \%$. Some studies on the transpiration of mountain plants reveal the dependence of changes in plant transpiration on the height of their habitat. According to Stanko et al. (1958), an increase in the intensity of transpiration in plants with elevation to greater height is due to an increase in light intensity. It is known that the intensification of transpiration leads to an increase in water deficiency. In Vavilovia, water deficit is compensated by well-developed root system, which increase absorbtion of water. Some other parameters obtained under in situ and ex situ conditions changed not so significantly and did not exceed statistical deviations.

\section{Conclusions}

The populations of Vavilovia formosa in Armenia, as well as in other sites of the world, are in danger of extinction and need both in situ and ex situ complementary investigation and conservation. The present investigation contribute to the bio-ecological knowledge on $V$. formosa of mountain Aknasar population (Gegham highland) and under ex situ conditions. As a result of population monitoring data on natural conditions, flora composition, ecological and coenotic characteristic of the habitat and bio-ecological features of $V$. formosa are given. One of the natural threats leading to the change and reduction of Vavilovia population were estimated the overgrowing of mobile scree habitat with turf-forming grasses, which creates conditions for the development of mountain-meadow vegetation. A slight increase in temperature and a decrease in air humidity in the alpine zone currently not adversely affect the vital activity of Vavilovia, which belongs to the eco-biological group of high mountain xerophytes. The present state of Vavilovia population of mountain Aknasar can be estimated as satisfactory. A large number of seedlings and juvenile Vavilovia plants were observed in population, which indicates the activation of seed reproduction along with vegetative propagation. $V$. formosa ex situ conservation strategy is one of the possible ways of its adaptive capacity estimation to environment changes. An introductory experiment on the cultivation of Vavilovia in the Yerevan and Sevan Botanical Gardens has started, some data on bio-morphological and eco-physiological peculiarities under ex situ conditions were obtained.

\section{References}

Akhverdov A A, Mirzoeva N V (1949): The experience of wild herbaceous plants collecting, keeping and planting in the Yerevan Botanical Garden of Academy of Sciences of Arm SSR. Bull. Bot. Sada Akad. Nauk. Arm SSR 8: 37-45.

Akhverdov A A, Mirzoeva N V (1961): The exhibition of the "Flora and Vegetation of Armenia" Plot. Bull. Bot. Sada Akad. Nauk. Arm SSR 18: 35-52.

Akhverdov A A, Mirzoeva N V (1964): The behavior of alpine plants transferring in stony wormwood semi-desert zone. Trudy Bot. Inst. Akad. Nauk. Arm SSR 14: 91-121.

Akopian J, Sarukhanyan N, Gabrielyan I, Vanyan A, Mikic A, Smykal P, Kenicer G, Vishnyakova M, Sinjushin A, Demidenko N, Ambrose M (2010): Reports on establishing an ex situ site for "beautiful" vavilovia (V avilovia formosa) in Armenia. Genetic Resources and Crop Evolution 57 (8): 1127-1134.

Akopian J A, Sinjushin A A, Gabrielyan I G, Shaboyan G G (2014): On some biomorphological peculiarities of seedlings of Vavilovia formosa (Steven) Fed. (Fabaceae). Legum Perspect. 5: 34-35

Akopian J A (2018): On the history of high-mountain pea Vavilovia formosa (Steven) Fed. (Fabaceae) investigation in Armenia. Takbtajania 4: 121-125.

Aslanyan A T (1958): The Regional Geology of Armenia. Yerevan

Baloyan S A (2004): List of the species of alpine flora of the Central Armenian volcanic highland. Flora, Vegetation and Plant Resources of Armenia 15: 97-107.

Beydeman I N (1974): Methods of plants and plant communities phaenological investigation. Novosibirsk

Fedorov An A (1939): Wild high-mountain peas of Caucasus. Trudy Biol. Inst. Arm. Fil. Akad. Nauk SSSR 1: 39-79.

Hill D, Fasham M, Tucker G, Shrewry M, Shaw P (2005): Handbook of biodiversity methods: survey, evaluation and monitoring. Cambridge 
Kazaryan Y S (1939): Materials for studying the vegetation of high mountain scree of Armenia. Proceedings of young scientists dedicated to the XX anniversary of the Komsomol. Armenian branch of the USSR Academy of Sciences. Yerevan: 245-268.

Makasheva R K, Drozd A M, Adamova O P, Golubev A A (1973): Perennial pea. Bull. Appl. Bot. Genet. and Plant Breeding 51: 44-56.

Melkonyan H, Gevorgyan A (2017): Climate change: the main characteristic assessment and trends scenario planning. Yerevan

Mezhunts B Kh, Navasardyan M A (2010): Method for the determination of chlorophyll $a, b$ and carotenoids in extracts of plants leaves. Patent for invention. No. 2439A. Yerevan

Mikić A, Smýkal P, Kenicer G, Vishnyakova M, Sarukhanyan N, Akopian J, Vanyan A, Gabrielyan I, Smýkalová I, Sherbakova E, Zorić L, Atlagić J, Zeremski-Škorić T, Ćupina B, Krstić Đ, Jajić I, Antanasović S, Đorđević V, Mihailović V, Ivanov A, Ochatt S, Ambrose M (2013): The bicentenary of the research on 'beautiful' Vavilovia (Vavilovia formosa), a legume crop wild relative with taxonomic and agronomic potential. Bot.J. Linn. Soc. 172: 524-531.

Mikić A, Smýkal P, Kenicer G, Vishnyakova M, Sarukhanyan N, Akopian J, Vanyan A, Gabrielyan I, Smýkalová I., Sherbakova E, Zorić L, Atlagić J, Zeremski-Škorić T, Ćupina B, Krstić Đ, Jajić I, Antanasović S, Đorđević V, Mihailović V, Ivanov A, Ochatt S, Toker C, Zlatković B, Ambrose M (2014): Beauty will save the world, but will the world save beauty? The case of the highly endangered V avilovia formosa (Steven) Fed. Planta 240(5): 1139-1146.

Osipova O P (1947): About the chlorophyll extraction from green plants. DAN SSSR 57 (8): 37-45.

Serebryakov I G (1962): Ecological Morphology of Plants. Moscow

Smýkal P, Chaloupská M, Bariotakis M, Marečková L, Sinjushin A, Gabrielyan I, Akopian J, Toker C, Kenicer G, Kitner M, Pirintsos S (2017): Spatial patterns and intraspecific diversity of the glacial relict legume species Vavilovia formosa (Steven) Fed. in Eurasia. Plant Syst. Evol. 303: 267-282.

Stanko S A., Bedenko V P, Nebogatikova M S (1958): The use of radiant energy by plants depending on vertical zonality. Works of the Astrobotany sector of the Academy of Sciences of the Kazakh SSR 6: 62-71.

Tamanyan K, Fayvush G, Nanagyulyan L, Danielyan T (eds.) (2010): The Red Book of Plants of the Republic of Armenia. Higher plants and Fungi. 2nd ed. Yerevan

Tretyakov N N (1990): Practicum on Plant Physiology, 3rd ed. Moscow

Vishnyakova M, Burlyaeva M, Akopian J, Murtazaliev R, Mikic A (2016): Reviewing and updating the detected locations of beautiful vavilovia (Vavilovia formosa) on the Caucasus sensu stricto. Genet. Resour. Crop Evol. 63(7): 1085-1102.

\title{
Istraživanja populacije višegodišnje biljke Vavilovia formosa (Fabaceae) na planini Aknasar (Gegamska visoravan) i u ex situ uslovima botaničkih bašta Jermenije
}

\author{
Janna Akopian - Anahit Ghukasyan - Zhanna Hovakimyan • \\ Lora Martirosyan - Gevorg Zaroyan
}

Sažetak: Divlji višegodišnji grašak Vavilovia formosa je reliktna i ugrožena vrsta koja pripada visokoplaninskoj (alpskoj) flori Jermenije i koja je prilagođena kamenitim, siparnim staništima. Populacije $V$. formosa u Jermeniji, kao i na drugim mestima u svetu, u opasnosti su od izumiranja i zahtevaju komplementarna in situ i ex situ proučavanja i očuvanje. Ovaj rad prikazuje proučavanja populacije $V$. formosa planine Aknasar, pružajući podatke o prirodnim uslovima, sastavu flore, ekološkim i biocenoznim karakteristikama staništa i bioekološkim obeležjima $V$. formosa. Sadašnje stanje populacije Vavilovia na planini Aknasar je zadovoljavajuće. Pored vegetativnog razmnožavanja, primećeno je aktiviranje razmnožavanja semenom. Jedna od prirodnih pretnji koja dovodi do promena i smanjenja populacije Vavilovia je obrastanje staništa pokretnog sipra busenastim travama, utičući na stvaranje uslova za razvoj planinskolivadske vegetacije. Strategija ex situ očuvanja $V$. formosa je jedan od mogućih načina procene njene sposobnost prilagođavanja na promene spoljašnje sredine, kao i način njenog očuvanja i korišćenja u osnovnim i primenjenim istraživanjima. Započeta ispitivanja mogućnosti gajenja vavilovije u Jerevanu i botaničkim baštama Sevana dala su podatke o njenim biomorfološkim i ekofiziološkim osobenostima u ex situ uslovima.

Ključne reči: bio-ekološka istraživanja, ex situ gajenje, Jermenija, planina Aknasar, V avilovia formosa 